\title{
Ani İşitme Kaybı (AİK) Hastalarının Hemoreolojik Parametrelerinin İncelenmesi
}

\author{
Mukaddes SINAN, Nesrin Zeynep ERTAN', Özlem YALÇIN², \\ Bengüsu MİRASOĞLU
}

\begin{abstract}
$\ddot{O} \mathbf{z}$
Amaç: Ani işitme kaybının (AİK) patofizyolojisi hakkında yeterli bilgi olmamakla birlikte, çeşitli yayınlarda, koklear kan akımında azalma, perilenfada oksijenlenmenin azalması gibi nedenler bildirilmiştir. Bu nedenle, ilaç tedavisinin yanında sıklıkla hiperbarik oksijen tedavisi (HBOT) de uygulanmaktadır. Ancak, bu tedavinin sonunda, çoğunlukla işitme geri gelse de bazen kulak çınlamasının devam etmesi, bu hastalarda koklear kan akımını etkileyen başka faktörlerin olabileceğini düşündürmektedir. Bu çalışmada, AİK sendromu ile kan akımı faktörlerinin ilişkisini araştırmak amacı ile bu hastaların hemoreolojik parametreleri incelenmiştir.
\end{abstract}

Gereç ve Yöntem: Bu çalışmaya 14 AİK hastası (yaş: $49.3 \pm 12.5$ ) ve diğer bölümlerden 15 normal işitmeli gönüllü (yaş: $46.8 \pm 11.1$ ) katılmıştır. Kan ve plazma viskoziteleri, koni / düzlem viskozimetresi (Wells-Brookfield) kullanılarak ölçülmüştür. Eritrosit deformabilite (ED) ve agregasyon (EA) parametreleri ise lazer uyumlu bir Ektasitometre (LO ${ }^{\circledR} R C A$, Mechatronics) ile ölçülmüştür. İstatistiksel analizler, Student-t ve Mann-Whitney U testleri kullanılarak yapılmıştır.

Bulgular: İki grup arasında yapılan analizlerde, agregasyon sonuçları arasındaki farklar (hasta/ kontrol) plazmada: amplitüd [AMP (au)]: 25.49/28.38 ( $p<0.01)$; agregasyon indeksi [AI $(\%)$ ]: $72.38 / 66.36(p<0.005)$ ve yarı süre [ $\left.\mathrm{t}_{1 / 2}(\mathrm{~s})\right]: 1.6 / 2.08(p<0.003)$, dekstran 70 solüsyonunda ise AMP: 40.11/46.92 $(p<0.002)$ istatistiksel olarak anlamlı bulunmuştur. Viskozite (kan ve plazma) ve deformabilite parametrelerinde ise anlamlı bir fark bulunamamıştır.

Sonuç: Verilerimiz, eritrosit agregasyonundaki olumsuz değişikliklerin, mikrodolaşım yolu ile ani işitme kaybının fizyopatolojisine önemli düzeyde katkı yaptığını düşündürmektedir.

Anahtar Kelimeler: Ani işitme kaybı, Kan viskozitesi, Plazma viskozitesi, Eritrosit deformabilitesi, Eritrosit agregasyonu

\footnotetext{
${ }^{1}$ İstanbul Aydın Üniversitesi, Tıp Fakültesi, Fizyoloji Anabilim Dalı

${ }^{2}$ Koç Üniversitesi, Tıp Fakültesi, Fizyoloji Anabilim Dalı

${ }^{3}$ İstanbul Üniversitesi, İstanbul Tıp Fakültesi, Sualtı Hekimliği ve Hiperbarik Tıp Anabilim Dalı

Yazışma adresi: Dr. Mukaddes SİNAN, İstanbul Aydın Üniversitesi, Tıp Fakültesi, Fizyoloji Anabilim Dalı, Küçükçekmece/İstanbul, Türkiye. Tel: +905369382232, E-mail: mukaddessinan@aydin.edu.tr, ORCID ID:0000-0002-7511-4737.

Geliş Tarihi: 09 Mart 2020 Kabul Tarihi: 17 Mart 2020

Doi num: 10.17932/IAU.TFK.2018.008/2020.301/tfk_v03i1004
} 


\title{
Investigation of Hemorheological Parameters of Sudden Sensorineural Hearing Loss (SSHL) Patients
}

\begin{abstract}
Objective: Although there is not enough information about the pathophysiology of sudden hearing loss (SSHL) several publications have reported factors such as reduction in the cochlear blood flow and decreased oxygenation in perilymph for SSHL syndrome. Therefore, hyperbaric oxygen therapy accompanies drug therapy in these patients. The hearing is usually recovered by the end of this treatment, but sometimes the continuation of the tinnitus suggests that there may be other factors influencing the cochlear blood flow. In this study, the relationship between this syndrome and hemorheological parameters have been investigated in patients with sudden hearing loss.

Materials and methods: Fourteen patients with SSHL (age: 49.3 \pm 12.5 ) and fifteen controls (age: 46.8 \pm 11.1 ) participated in the study. Whole blood and plasma viscosity were measured using acone/plate viscometer (Wells-Brookfield). Erythrocyte deformability (ED) and aggregation (EA) indices were measured using alaser diffraction Ektacytometer (LO $\left.{ }^{2} R C A\right)$. Student-t test and Mann-Whitney $U$ tests were performed for the statistical analysis of the data.

Results: Our findings showed that there were significant differences between patients and controls in terms of aggregation parameters (In plasma: amplitude [AMP (au)]: 25.49/28.38, $p<0.01$; aggregation index [AI (\%)]: 72.38/66.36; $p<0.005$ and half time [ $\mathrm{t}_{1 / 2}$ (s)]: 1.6/2.08; $p<0.003$. In dextran solution: AMP: 40.11/46.92; $p<0.002$; as patients/controls). There were no significant differences in viscosity (blood and plasma) and deformability parameters.

Conclusion: Our data suggest that the changes in aggregation indices, which affect microcirculation, may contribute negatively on the physiopathology of SSHL.
\end{abstract}

Keywords: Sudden hearing loss syndrome, Whole blood viscosity, Plasma viscosity, Erythrocte deformability, Erythrocyte aggregation

\section{Giriş}

Ani işitme kaybı (AİK), çoğunlukla üç gün içinde belli bir nedene bağlı olmadan meydana gelen ve odyogramda birbirini takip eden en az üç frekansta 30 desibelden daha fazla bir kayıpla ortaya çıkan tipte işitme kaybı olarak tanımlanır. Yıllık AİK görülme sıklığının 100.000 kişi başına 5-20 hasta olduğu tahmin edilmektedir. AİK'nin etiyolojisi henüz tanımlanmamakla birlikte AİK'ye neden olan çeşitli faktörler ileri sürülmektedir. Bu faktörler arasında, çok sayıda yayınla desteklenen viral enfeksiyon, otoimmün hastalık ve vasküler bozukluk vardır. Son yıllarda AİK'de yaygın olarak kabul edilen en önemli faktör, vasküler mikrodolaşım bozukluğudur. Koklear arter bir uç arterdir ve beslenme konusunda kollateral damarlardan yardım almaz. $\mathrm{Bu}$ nedenle, koklear fonksiyon vasküler hasarlara duyarlıdır. Bu hasarlar arasından koklear vasküler tıkanıklık ve kan akımı azalması, koklear fonksiyonu değiştiren olası mekanizmalar olarak kabul edilmiştir ve koklear mikrodamarlardaki değişiklikler ile ilişkilidir $(1,2)$. Deneysel hayvan modelli çalışmalarda da, iç kulakta vasküler tıkanıklık oluşturulduğunda meydana gelen koklear değişikliklerin histopatolojik olarak gösterilmesi (3), koklear kan akımının bozulmasının, işitsel yanıtta önemli bir kayıp ile sonuçlandığını göstermiştir $(1,2)$.

AİK'nin tedavisinde hastalığın olası nedenlerine yönelik kortikosteroidler, vazodilatörler, antikoagülanlar, vitaminler, histamin tedavisi, antiviral ajanlar kullanılmakta ve bunların yanında hiperbarik oksijen tedavisi (HBOT) uygulanmaktadır. Günümüzde steroid ile HBOT'nin kombine tedavisi en çok uygulanan tedavi yöntemidir (4). Tedavide kullanılan bu yöntemler oksijenlenmeyi arttırmaya, mikrodolaşımı düzeltmeye, ödemi azaltmaya ve otoimmün hasarı baskılamaya yöneliktir (5). 
Hemoreoloji, kan akımı ile eritrosit deformabilitesi (ED) ve agregasyonu (EA) gibi kan hücrelerinin ve plazmanın damar içindeki davranışını inceleyen bir bilimdir (6). Kan akımı, doku perfüzyonunun korunmasında önemli bir rol oynar (7). Birçok klinik çalışmada, kan akışkanlığı ile kan dolaşımını da içeren çeşitli hastalıkların şiddeti arasındaki ilişki doğrulanmıştır. Çeşitli patolojik koşullarda, azalmış eritrosit deformabilitesi ve artmış eritrosit agregasyonu gibi akış davranışındaki değişikliklerin yanı sıra, plazma ve kan viskozitesinde de artışlar gösterilmiştir (8-11). Bazı çalışmalar hemoreolojik değişikliklerin koklear vasküler tıkanıklık ile ilişkili olabileceğini rapor etmiştir $(2,12,13)$. Kan hücrelerinde ve plazma proteinlerinde meydana gelen değişikliklere bağlı oluşan bu hemoreolojik değişiklikler, özellikle mikrovasküler bölgede, rulo oluşumu yoluyla kan akışının yavaşlamasına neden olabilecek bir hiperviskoziteye yol açar $(2,14,15)$. Diğer yandan, AİK hastalarında tam kan viskozitesinde artma ve ED'de azalma gibi hemoreolojik değişiklikler de bildirilmiştir $(2,16$, 17).

$\mathrm{Bu}$ bilgilerin ışığında, biz de çalışmamızda AİK olan hastalarda, bu sendrom ile mikrodolaşımda önemli bir rolü olan hemoreolojik parametrelerin ilişkisini araştırmayı amaçladık.

\section{Gereç ve Yöntem}

\section{Çalışmaya Katılan Hastalar ve Kan Alınması}

İstanbul Üniversitesi Tip Fakültesi Etik Kurulu'ndan 2016 tarih 371 sayı ile onay alındıktan sonra çalışmaya, İstanbul Üniversitesi, İstanbul Tıp Fakültesi, Sualtı Hekimliği ve Hiperbarik Tıp Anabilim Dalı Polikliniği’ne, HBOT için başvuran 14 AİK hastası ve 15 normal işitmeli gönüllü katıldı. Hastalara, çalışma ile ilgili yazılı ve sözlü bilgi verildikten sonra, çalışmaya katılmayı kabul eden hastalardan yazılı onam formu alındı. Çalışmaya katılan deneklerden hemoreolojik testler için $10 \mathrm{~mL}$ etilendiamintetraasetik asitli (EDTA) tüplere venöz kan alındı.

\section{Hemoreolojik Parametrelerin Ölçülmesi}

\section{1) Hematokrit (Hct) Tayini}

Hct tayini için mikrohematokrit metodu uygulandı. Deneklerden alınan kandan, heparinli Hct kapiller tüpünün bir ucundan 2/3'sine kadar kan çekildi. Diğer ucu Hct macunu ile kapatıldıktan sonra 9000 rpm'de 4 dk santrifüj edildi (Elektromag M19). Hematokrit cetveli ile \%Hct ölçüldü.

Doğal hematokriti ölçülmüş kan örneklerinden doğal kan viskozitesi ölçümü için $0.5 \mathrm{~mL}$ kan ayrıldıktan sonra geri kalan kan örnekleri, 3000 rpm'de 10 dk santrifüj edildi (Nüve-NF 1215). Hct, başlangıç değerlerine göre, plazma ekleyerek ya da çıkarılarak \%45 olarak ayarlandı. $0.5 \mathrm{~mL}$ plazma ise plazma viskozitesi ölçümü için ayrıldı.

\section{2) Kan ve Plazma Viskozitesi Ölçümü}

Kan ve plazma viskozitesi ölçümü, koni / düzlem viskozimetresi (Wells-Brookfield, cone / plate viscometer) kullanılarak $37^{\circ} \mathrm{C}$ 'de yapıldı. Doğal kan viskozitesi ölçümü için ayrılan ve Hct'si $\% 45$ 'e ayarlanmış (düzeltilmiş) $0.5 \mathrm{~mL}$ kan, viskozimetrenin haznesine konularak 8 farklı kayma hizinda $(75,150,185,300,375,750,1350$ ve 1500 $\left.\mathrm{s}^{-1}\right)$ kan viskoziteleri ölçüldü. Plazma viskozitesi ise $0.5 \mathrm{~mL}$ plazma kullanılarak, $300 \mathrm{~s}^{-1}$ uygulanarak ölçüldü (18).

\section{3) Eritrosit Deformabilitesi Ölçümü}

Eritrosit deformabilitesi ölçümleri, Koç Üniversitesi Tıp Fakültesi'nde Hemoreoloji Laboratuvarı'nda Ektasitometre (LOßRCA Ectacytometer, RR Mechatronics, Hoorn, The Netherlands) kullanılarak $37^{\circ} \mathrm{C}$ 'de yapıldı. LORCA'nın standart kullanım metodu, daha önce Hardeman ve ark. tarafindan tanımlanan metoda göre uygulandı (19). Buna göre, Hct'si plazma ile \%45'e ayarlanmış $25 \mu \mathrm{L}$ kan, viskozitesi $29.7 \mathrm{mPa}$. sn olan $5 \mathrm{~mL}$ 'lik polivinilpirolidon (PVP) solüsyonuna (Sigma PVP360, RR Mechatronics, Hoorn, The Netherlands) eklenerek karıştırıldı. Bu karışımdan alınan $1.5 \mathrm{~mL}$ kan süspansiyonu, aralarında $0.3 \mathrm{~mm}$ boşluk olan iki cam silindirden oluşan bir sisteme yerleştirildi. $\mathrm{Bu}$ sistemin çalışma prensibine göre, iç kısımdaki sabit silindirin içinde yer alan lazer kaynağından çıkan 1şın, eritrosit süspansiyonuna ulaşır. Bir ekran üzerine yansıyan difraksiyon paterni de (lazer ışığın hücreler üzerine yansımasıyla elde edilen şekil), süspansiyondaki eritrositlerin şekil değişikliğini yansıtır. Cam silindirlerden dış kısımda olanı çeşitli hızlarla döner ve böylece araya konulan kan, 
farklı kayma kuvvetlerinin etkisi altında bırakılır. Artan kayma kuvvetlerine paralel olarak bu patern, dairesel bir formdan elipsoid bir forma dönüşür. $\mathrm{Bu}$ değişim oranı elongasyon indeksi [eritrosit uzama derecesi değerleri, (EI)] olarak değerlendirilir. Bizim çalışmamızda da, elongasyon indeksi 0.350 pascal $(\mathrm{Pa})$ arasında otomatik olarak değişen 10 değişik kayma kuvvetinde (shear stress - SS) ölçülerek değerlendirildi (19).

\section{4) Eritrosit Agregasyonu Ölçümü}

Eritrosit agregasyonu, yine LORCA ile ancak farklı bir sistem düzenlemesi ile ölçüldü. Bu sistemde, ışığın zamanla geri yansıma yoğunluğundaki (lsc) değişimi değerlendirilir ve sylectogram olarak adlandırılan bir grafik çizilir. Bu ölçüm esnasinda, agregasyon parametreleri olarak, AMP; agregasyonun genliği, $\mathrm{t}^{1} / 2$; tam agregasyonun yarıs kadar agregasyonun meydana geldiği süreyi ve $\mathrm{AI}$; agregasyonun kinetiğini ifade etmektedir $(19,20)$.

Agregasyon ölçümleri için, santrifüj edilip plazmasından ayrılmış ve buffy coat tabakası çıkarılmış eritrosit paketinden farklı iki kan süspansiyonu hazırlandı:

1- Önceden ayrılmış kendi plazması ile (otolog plazma) \%45 Hct'ye ayarlanmış eritrosit süspansiyonu.

2- Yüksek moleküler ağırlıklı ve fibriller yapıdaki bir biyomolekül olan dekstran [izotonik \%3 konsantrasyonlu dekstran 70 (Mol ağırlığı: 70.000)] kullanılarak hazırlanan yine $\% 45$ Hct oranında eritrosit süspansiyonu.

Plazma süspansiyonundan $1.5 \mathrm{~mL}$ alınarak LORCA cihazındaki ölçüm haznesine yerleştirildi ve $37^{\circ} \mathrm{C}$ 'de ölçüm yapıldı. Ardından ölçüm dekstran 70 süspansiyonu için tekrarlandı.

Elde edilen verilerin değerlendirilmesinde SPSS 21.0 paket programı kullanıldı. Veriler ortalama \pm standart sapma (ort \pm ss) ile verildi. Verilerin normalliği Shapiro-Wilks testi kullanılarak test edildikten sonra normal dağılım gösteren verilere Student's t-test (t-testi), normal dağ 11 im göstermeyen veriler için ise Mann Whitney-U analizleri kullanıldı. Anlamlılık düzeyi $\mathrm{p} \leq 0.05$ olarak kabul edildi.

\section{Bulgular}

AİK hastalarının yaşları: $49.3 \pm 12.5$ ve 19 normal işitmeli sağlıklı gönüllülerin yaşları ise $46.8 \pm 11.1$ olarak bulundu. Gruplar istatistiksel olarak uyumlu idi.

Hasta ve kontrol grupları arasında yapılan istatistiksel analiz sonucunda \%Hct ve plazma viskozitesi değerlerinde anlamlı bir fark görülmedi (Tablo 1).

Tablo 1. Hasta ve Kontrol Gruplarının \%Hct ve Plazma Viskozitesi Değerleri

\begin{tabular}{lccc}
\hline & Hasta Grubu $(\mathbf{n = 1 4})$ & Kontrol Grubu $(\mathbf{n}=\mathbf{1 5})$ & $\boldsymbol{p}$ \\
\hline \%Hct & $43.84 \pm 2.65$ & $41.42 \pm 6.11$ & 0.252 \\
\hline Plazma Viskozitesi (cP) & $1.63 \pm 0.10$ & $1.6 \pm 0.089$ & 0.289 \\
\hline
\end{tabular}

Hct: Hematokrit, cP: Centipoise.

Hasta ve kontrol gruplarının 8 farklı kayma hızında, doğal kan viskozitesi ve $\% 45$ 'e ayarlanan düzeltilmiş kan viskozitesi ölçüm değerleri Tablo 2'de gösterildi. Sonuçların istatistiksel olarak karşılaştırılmasında AİK ve normal işitmeli grup arasında anlamlı bir fark görülmedi. 
Tablo 2. Hasta ve Kontrol Gruplarının Doğal Kan Viskozitesi ve Düzeltilmiş Kan Viskozitesi Değerleri

\begin{tabular}{|c|c|c|c|c|c|}
\hline \multirow[b]{2}{*}{$\begin{array}{l}\text { Kayma } \\
\text { Hızı }\end{array}$} & \multicolumn{2}{|c|}{ Hasta Grubu } & \multicolumn{2}{|c|}{ Kontrol Grubu } & \multirow[b]{2}{*}{$p$} \\
\hline & $\begin{array}{c}\text { Doğal Kan } \\
\text { Viskozitesi (cP) }\end{array}$ & $\begin{array}{c}\text { Düzeltilmiş Kan } \\
\text { Viskozitesi } \\
\text { (cP) }\end{array}$ & $\begin{array}{l}\text { Doğal Kan } \\
\text { Viskozitesi } \\
\quad \text { (cP) }\end{array}$ & $\begin{array}{l}\text { Düzeltilmiş Kan } \\
\text { Viskozitesi (cP) }\end{array}$ & \\
\hline $75 s^{-1}$ & $6.01 \pm 0.86$ & $6.60 \pm 0.73$ & $6.14 \pm 0.78$ & $6.42 \pm 0.52$ & $\begin{array}{l}p^{1}=0.559 \\
p^{2}=0.596\end{array}$ \\
\hline $150 \mathrm{~s}^{-1}$ & $5.24 \pm 0.78$ & $5.67 \pm 0.78$ & $5.40 \pm 0.73$ & $5.57 \pm 0.50$ & $\begin{array}{l}p^{I}=0.511 \\
p^{2}=0.884\end{array}$ \\
\hline $185 \mathrm{~s}^{-1}$ & $4.92 \pm 0.73$ & $5.28 \pm 0.59$ & $5.13 \pm 0.59$ & $5.27 \pm 0.43$ & $\begin{array}{l}p^{l}=0.315 \\
p^{2}=0.942\end{array}$ \\
\hline $300 \mathrm{~s}^{-1}$ & $4.57 \pm 0.70$ & $4.88 \pm 0.46$ & $4.80 \pm 0.54$ & $4.94 \pm 0.35$ & $\begin{array}{l}p^{I}=0.290 \\
p^{2}=0.676\end{array}$ \\
\hline $375 \mathrm{~s}^{-1}$ & $4.43 \pm 0.69$ & $4.68 \pm 0.43$ & $4.63 \pm 0.54$ & $4.77 \pm 0.35$ & $\begin{array}{l}p^{I}=0.266 \\
p^{2}=0.443\end{array}$ \\
\hline $750 \mathrm{~s}^{-1}$ & $4.02 \pm 0.58$ & $4.27 \pm 0.36$ & $4.20 \pm 0.50$ & $4.32 \pm 0.34$ & $\begin{array}{l}p^{l}=0.382 \\
p^{2}=0.743\end{array}$ \\
\hline $1350 \mathrm{~s}^{-1}$ & $3.78 \pm 0.54$ & $4.01 \pm 0.33$ & $3.98 \pm 0.49$ & $4.08 \pm 0.34$ & $\begin{array}{l}p^{I}=0.316 \\
p^{2}=0.771\end{array}$ \\
\hline $1500 \mathrm{~s}^{-1}$ & $3.73 \pm 0.54$ & $3.96 \pm 0.33$ & $3.94 \pm 0.49$ & $4.04 \pm 0.34$ & $\begin{array}{l}p^{l}=0.321 \\
p^{2}=0.702\end{array}$ \\
\hline
\end{tabular}

Değerler ortalama \pm standart sapma olarak verilmiştir. $\mathrm{s}^{-1}=$ Resiprok sn, cP: Centipois, $p^{l}$ : Hasta ve kontrol gruplarının doğal kan viskozitesi, $p^{2}$ : Hasta ve kontrol gruplarının düzeltilmiş kan viskozitesi. Anlamlılık sınırı $p \leq 0.05$ olarak kabul edilmiştir.

10 farklı SS uygulanarak ölçülen EI değerleri Tablo 3'de gösterildi. Tablo 3'de görüldüğü gibi, hasta ve kontrol gruplarına ait EI değerlerinin istatistiksel olarak karşılaştırılmasında anlamlı bir fark görülmedi.
Hasta ve kontrol gruplarının otolog plazma ve dekstran 70 solüsyonu için eritrosit agregasyon parametreleri Tablo 4'de gösterildi. İki grup karşılaştırıldığında; otolog plazmada, AİK hastalarının AMP ve $t^{1} / 2$ değerlerinin kontrol grubuna göre istatistiksel olarak anlamlı şekilde düşük olduğu (sırasıyla; $\mathrm{p}<0.01, \mathrm{p}<0.003$ ), AI değerinin ise yüksek olduğu $(\mathrm{p}<0.005)$ görüldü. Dekstran 70 solüsyonunda ise, AİK hastalarının AMP değerinin kontrol grubuna göre istatistiksel olarak anlamlı şekilde düşük olduğu görülürken $(p<0.002)$, AI ve $t^{1} \frac{1}{2}$ değerlerinde anlamlı bir fark görülemedi. 
Tablo 3. Hasta ve Kontrol Gruplarının 10 Farklı SS'de EI Değerleri

\begin{tabular}{llll}
\hline & Hasta Grubu & Kontrol Grubu & $\boldsymbol{p}$ \\
\hline $\mathbf{0 . 3} \mathbf{P a}$ & $0.0359 \pm 0.0442$ & $0.0194 \pm 0.0115$ & 0.264 \\
\hline $\mathbf{0 . 5 3} \mathbf{P a}$ & $0.0889 \pm 0.0228$ & $0.0760 \pm 0.0183$ & 0.187 \\
\hline $\mathbf{0 . 9 4} \mathbf{~ P a}$ & $0.1622 \pm 0.0272$ & $0.1493 \pm 0.0210$ & 0.361 \\
\hline $\mathbf{1 . 6 5} \mathbf{~ P a}$ & $0.2545 \pm 0.0314$ & $0.2363 \pm 0.0222$ & 0.201 \\
\hline $\mathbf{2 . 9 1} \mathbf{~ P a}$ & $0.3547 \pm 0.0315$ & $0.3398 \pm 0.0186$ & 0.194 \\
\hline $\mathbf{5 . 1 5} \mathbf{P a}$ & $0.4428 \pm 0.0317$ & $0.4305 \pm 0.0158$ & 0.248 \\
\hline $\mathbf{9 . 0 9} \mathbf{P a}$ & $0.5102 \pm 0.0264$ & $0.5063 \pm 0.0127$ & 0.598 \\
\hline $\mathbf{1 6 . 0 4} \mathbf{P a}$ & $0.5570 \pm 0.0207$ & $0.5594 \pm 0.0108$ & 0.839 \\
\hline $\mathbf{2 8 . 3 2} \mathbf{P a}$ & $0.5900 \pm 0.0150$ & $0.5957 \pm 0.0077$ & 0.503 \\
\hline $\mathbf{5 0} \mathbf{P a}$ & $0.6144 \pm 0.0100$ & $0.6186 \pm 0.0051$ & 0.231 \\
\hline Deger &
\end{tabular}

Değerler ortalama \pm standart sapma olarak verilmiştir. EI: Elongasyon indeksi, Pa: Pascal.

Tablo 4. Otolog Plazma ve Dekstran 70 için Hasta ve Kontrol Gruplarının AMP, AI ve t¹/2 Değerleri

\begin{tabular}{|c|c|c|c|c|c|}
\hline & \multicolumn{2}{|c|}{ Hasta Grubu } & \multicolumn{2}{|c|}{ Kontrol Grubu } & \multirow[b]{2}{*}{$p$} \\
\hline & Plazma & Dekstran 70 & Plazma & Dekstran 70 & \\
\hline AMP (au) & $25.49 \pm 3.86$ & $40.11 \pm 6.99$ & $28.38 \pm 1.82$ & $46.92 \pm 2.47$ & $\begin{array}{l}p^{1}<0.01 \\
p^{2}<0.002\end{array}$ \\
\hline AI (\%) & $72.38 \pm 9.07$ & $68.93 \pm 4.19$ & $66.36 \pm 6.77$ & $69.76 \pm 2.06$ & $\begin{array}{l}p^{1}<0.005 \\
p^{2}=0.942\end{array}$ \\
\hline $\mathbf{t}^{1 / 2}(\mathbf{s})$ & $1.6 \pm 1.01$ & $1.82 \pm 0.40$ & $2.08 \pm 0.74$ & $1.68 \pm 0.19$ & $\begin{array}{l}p^{1}<0.003 \\
p^{2}=0.542\end{array}$ \\
\hline
\end{tabular}

Değerler ortalama \pm standart sapma olarak verilmiştir. AMP: Agregasyonun genişliği, AI: Agregasyon indeksi ve $\mathrm{t}^{1} / 2$ : Max. agregasyonun yarısı için gerekli süre. $p^{1}$ : Hasta ve kontrol gruplarının otolog plazmada, $p^{2}$ : Hasta ve kontrol gruplarının dekstran 70 solüsyonunda.

\section{Tartışma}

AİK'ye neden olan mekanizma henüz tanımlanmamış olmakla birlikte yapılan bir çalışmada, koklear mikrodolaşımda azalma olduğu ileri sürülmüştür (2). Kokleanın normal fonksiyonu, hem hücre içi hem de hücre dışı ortama, özellikle de koklear mikrodolaşıma dayalıdır. Koklear arter, bir uç arterdir ve beslenme konusunda kollateral damarlardan yardım almaz. Bu nedenle, koklear mikrodolaşım, kan akımının azalmasına ve vasküler oklüzyonlara karşı son derece hassastır $(1,21)$. Hemoreolojik parametreler, mikrodolaşımın korunmasında ve düzenlenmesinde önemli bir rol oynar. Kan hücreleri ve plazma bileşenlerindeki değişikliklere bağlı oluşan hemoreolojik 
değişiklikler, kan akımını yavaşlatabilecek ve rulo oluşumu yoluyla oklüziv hastalık gelişimini kolaylaştırabilecek hiperviskoziteye yol açar. Kan viskozitesinin düşük olması durumunda mikrodolaşımda iyileşme görülürken, EA artış1 mikrodolaşımın bozulmasına neden olur (22). Bu çalışmada, AİK'nin olası nedenlerinden birinin vasküler mikrodolaşım bozukluğu olmasından yola çıkarak bir grup AİK hastasını hemoreolojik açıdan analiz ettik.

Kan viskozitesi hemoreolojik parametreleri oluşturan en önemli faktörlerden biri olmakla birlikte Hct, plazma içeriği ve kan hücrelerinin reolojik özelliklerinden etkilenmektedir. Çalışmamızda denek gruplarının kan viskoziteleri, hem doğal Hct değerinde hem de Hct farklılıklarının kan viskozitesi üzerine etkisini ortadan kaldırmak için, Hct değerleri literatüre uygun olarak \%45'e ayarlandıktan sonra "düzeltilmiş kan viskozitesi" olarak ölçüldü (23). Sonuçlarımıza göre, 8 farklı kayma hızı değerinde, hem doğal hem de düzeltilmiş kan viskozitesi ölçümleri sonucunda hasta ve kontrol grupları arasında anlamlı bir fark görülmedi. Bulgularımızın; çeşitli yayınlarda, AİK olan kişilerde kan viskozitesinin yüksek olduğunu gösteren çalışmaların bulguları ile uyumsuzluk gösterdiği görülmektedir $(1,2,16$, 24). Bu çalışmalarda; yükselmiş kan viskozitesi ve mikrodolaşımın engellenmesinin, koklear hasar oluşumunun bir sonucu olarak işitme kaybına neden olan bir reolojik değişiklik ile ilişkili olduğu düşünülmüştür (25). Çalışmamızda yapılan Hct ölçümleri sonucunda hasta ve kontrol grupları arasında anlamlı bir fark görülememiştir. Çalışmamızda saptamış olduğumuz bu sonuç, literatürde; Mannini ve ark'nın, 63 AİK hastasında Hct değerini kontrol grubuna göre yüksek (2), buna zit olarak, Yasan ve ark'nın, 147 AİK hastasında Hct değerini kontrol grubuna göre düşük (26) buldukları çalışma sonuçlarıyla uyumsuzluk göstermektedir. Bir vücut stres altındayken, norepinefrin, epinefrin ve katekolamin salgılanmasının yanı sıra Hct ve kan viskozitesi de önemli ölçüde artar. Nöroendokrin faktörler, doğrudan veya dolaylı olarak, eritrositlerin yüzey yükü dağılımını değiştirebilir ve kan viskozitesini artırabilir. Bu durum, koklear mikrodolaşımın bozulmasına neden olur (1). Yukarıda bahsettiğimiz gibi; kan viskozitesi, plazma viskozitesindeki değişikliklerden de etkilenmektedir (23). Çalışmamızda hasta ve kontrol grubunun plazma viskozitesi ölçüm değerleri arasında anlamlı bir fark görülmemiştir. Çalışmamızda saptamış olduğumuz bu sonuçlar, literatürde AİK hastalarının plazma viskozitesinin kontrol grubuna göre yüksek olduğunu gösteren sonuçlar ile de uyumlu bulunmamıştır $(1,2,16$, 27).

ED, dolaşımın normal olarak devamı için son derece önemlidir. Koklea, terminal bir kapillerlerle dolu doku tabakası ile donatılmıştır ve iskemik bölgelerde kan akışını yeniden sağlayabilecek kolateral damarları oluşturamaz. Ayrıca, koklear hücreler özellikle kan akımının azalmasına karşı duyarlıdır ve bu alanda oluşan tıkanıklıklar koklear iskemiye yol açabilir. ED'nin azalması, mikrodolaşımı bozar (24). AİK de, ED ile ilişkilendirilmiş ve daha önceden yapılan çalışmalarda, AİK hastalarında kontrol grubuna göre ED'nde azalma gösterilmiştir (2, 17, 24, 25). $\mathrm{Bu}$ azalmanın, koklear mikrovasküler bölgede kan akımını azaltarak AİK patofizyolojisine yol açtığ 1 düşünülmektedir (2). Ancak bizim çalışmamızda, 10 farklı SS uygulanarak yapılan ED ölçümleri sonucunda, hasta ve kontrol grupları arasında anlamlı bir fark görülmedi.

Eritrosit agregasyonu; eritrositlerin geçici olarak birbirine bağlanarak kümeler oluşturmasıdır. Suckfüll ve ark. tarafindan, 53 AİK hastası ile yapılan bir çalışmada eritrosit agregasyonunun kontrol grubundan yüksek olduğu gösterilmiştir (27). Yüksek kayma hızlarında eritrositler serbest parçacıklarolarakhareketederve kan viskozitesi esas olarak; eritrosit konsantrasyonu, plazma viskozitesi ve eritrosit deformabilitesi ile belirlenirken, düşük kayma hızlarında eritrositler rulo oluşturduğundan ağırlıklı olarak eritrosit konsantrasyonu ve agregasyon özellikleri ile belirlenir $(2,22)$. Bununla birlikte, çeşitli çalışmalarda düşük kayma hızı uygulanarak yapılan kan viskozitesi ölçümü sonrasında AİK hastalarının kan viskozitesinin kontrol grubundan yüksek olduğunun görülmesi, eritrosit agregasyonunun da yüksek olduğunun bir 
göstergesidir $(1,2)$. Bizim çalı̧̧mamızda, hasta ve kontrol gruplarının otolog plazma ile yapılan eritrosit agregasyon ölçümlerinde, AİK hastalarının AMP ve $t^{1} / 2$ değerlerinin kontrol grubuna göre düşük olduğu, AI değerinin ise yüksek olduğu görüldü. Dekstran 70 solüsyonunda ise, AİK hastalarının AMP değerinin kontrol grubuna göre düşük olduğu görülürken, diğer parametrelerde anlamlı bir fark görülmedi. AMP ve AI değerinin artması ile $t^{1} / 2$ değerinin azalması; eritrosit agregasyonunda artma olduğunun göstergesi olarak kabul edilmektedir (20).

\section{Sonuc}

$\mathrm{Bu}$ bulgular bize, eritrosit agregasyonundaki olumsuz değişikliklerin, mikrodolaşım yolu ile ani işitme kaybının fizyopatolojisine önemli düzeyde katkı yaptığını düşündürmektedir. AİK olan hastalarda kontrol grubuna göre, AI değerinin yüksek, $t^{1} 12$ değerinin düşük görülmesinden dolayı eritrositlerin agregasyon eğiliminin yüksek olması, bu sendromun, ileride bu hastalarda, enfarktüs gibi ciddi komplikasyonları meydana getirebileceğinin göstergesi olabileceğini ve bu hastaların kardiyovasküler kontrol altında tutulmalarının önlem olarak gerekli olduğunu düşünmekteyiz. $\mathrm{Bu}$ konuda çalışmalarımız devam etmektedir.

\section{KAYNAKLAR}

1. Lu YY, Jin Z, Tong BS et al. A clinical study of microcirculatory disturbance in Chinese patients with sudden deafness. Acta Otolaryngol 2008; 128(11): 1168-72. doi: 10.1080/00016480801901626.

2. Mannini L, Paniccia R, Cecchi E et al. Reduced erythrocyte deformability and hypercoagulability in idiopathic sudden sensorineural hearing loss. Clin Hemorheol Microcirc 2005; 33(1): 47-55.

3. Scheibe F, Hauptand H, Baumgartl H. Effects of experimental cochlear thrombosis on oxygenation and auditory function of the inner ear. Eur Arch Otorhinolaryngol 1997; 254: 91-94.

4. Fujimura $T$, Suzuki $H$, Shiomori $T$ et al. Hyperbaric oxygen and steroid therapy for idiopathic sudden sensorineural hearing loss. Eur Arch Otorhinolaryngol 2007; 264(8): 861-866.
5. Koç C. Kulak Burun Boğaz Hastalıkları Ve Baş Boyun Cerrahisi. 2. Baskı Ankara: Güneş Kitapevi; 2013. s.193-201.

6. Baskurt OK, Meiselman HJ. Blood rheology and hemodynamics. Semin Thromb Hemost 2003; 29(5): 435-450.

7. Holsworth RE Jr, Cho YI, Weidman JJ et al. Cardiovascular benefits of phlebotomy: Relationship to changes in hemorheological variables, Perfusion 2014; 29(2): 102-116.

8. Ugurlu E, Kilic-Toprak E, Can I et al. Impaired hemorheology in exacerbations ofCOPD. Can Respir J 2017; 1286263. doi: 10.1155/2017/1286263.

9. Preibsch H, Keymel S, Kelm $M$ et al. Comparison of the simple red blood cell adhesiveness/aggregation test with the laserassisted optical rotational cell analyzer: Red blood cell aggregation in patients with coronary artery disease and a healthy control group. Clin Hemorheol Microcirc 2017; 65(4): 363-371. doi: 10.3233/CH-16201.

10. Tikhomirova I, Petrochenko E, Muravyov A et al. Microcirculation and blood rheology abnormalities in chronic heart failure. Clin Hemorheol Microcirc 2017; 65(4): 383-391. doi: 10.3233/CH-16206.

11. Biro K, Sandor B, Kovacs D et al. Lower limb ischemia and microrheological alterations in patients with diabetic retinopathy. Clin Hemorheol Microcirc 2018; 69(1-2): 23-35. doi: 10.3233/CH189103.

12. Lalanne MC, Doutremepuich $\mathrm{C}$, Boj F et al. Some hemostatic and hemorheological disorders in auditory and vestibular impairments. Thromb Res 1992; 66: 787-791.

13. Browning GG, Gatehouse S, Lowe GDO. Blood viscosity as a factor in sensorineural hearing impairment. Lancet 1 1986; 121-123.

14. Chien S, Usami S, Taylor HM et al. Effects of hematocrit and plasma proteins on human blood rheology at low shear rates. J Appl Physiol 1966; 21: 81-87. 
15. Schmid-Schönbein $H$, Gallasch $G$, Volger E et al. Microrheology and protein chemistry of pathological red cell aggregation (blood sludge) studied in vitro. Biorheology 1973;10: 213-227.

16. Ohinata $\mathrm{Y}$, Makimoto $\mathrm{K}$, Kawakami $\mathrm{M}$ et al. Blood viscosity and plasma viscosity in patients with sudden deafness. Acta Otolaryngol 1994; 114: 601-607.

17. Ciuffetti G, Scardazza A, Serafini G et al. Whole-blood filterability in sudden deafness. Laryngoscope 1992; 101: 65-67.

18. More solutions to sticky problems: A guide to getting more from your Brookfield Viscometer \& Rheometer, Brookfield Engineering Laboratories, Inc., Milddleborough, Massachusetts, USA 2003.

19. Hardeman MR, Goedhart PT, Dobbe JGG et al. Laser assisted optical rotational cell analyzer (LORCA): A new instrument for measurement of various structural hemorheological parameters. Clin Hemorheol Microcirc 1994; 14: 605-618.

20. Hardeman MR, Dobbe JGG, Ince C. The laserassisted optical rotational cell analyzer (LORCA) as red blood cell aggregometer. Clin Hemorheol Microcirc 2001; 25: 1-11.

21. Seidman MD, Quirk WS, Shirwany NA. Mechanisms of alterations in the microcirculation of the cochlea. Ann N Y Acad Sci 1999; 884: 22632.
22. Mannini L, Cecchi E, Fatini $\mathrm{C}$ et al. Clinical haemorheology and microcirculation. Ann Ist Super Sanita 2007; 43(2): 144-155.

23. Lowe GDO, Barbenel JC. Plasma and blood viscosity. Lowe GDO, editors. In: Clinical Blood Rheology, Boca Raton: CRC Press; 1988. p. 11-44.

24. Becatti M, Marcucci R, Mannucci A et al. Erythrocyte membrane fluidity alterations in sudden sensorineural hearing loss patients: The role of oxidative stress. Thromb Haemost 2017; 117(12): 2334-2345. doi: 10.1160/TH17-05-0356.

25. García-Callejo FJ, Marco-Algarra J, Pla-Gil I et al. Pathologic erythrocyte deformability in patients with sudden sensorineural hearing loss. Acta Otorrinolaringol Esp 2012; 63(4): 249-257.

26. Yasan H, Tüz M, Yariktaş $M$ et al. The significance of routine laboratory parameters in patients with sudden sensorineural hearing loss. Indian J Otolaryngol Head Neck Surg 2013; 65(Suppl 3): 553-556. doi: 10.1007/s12070-0120480-2.

27. Suckfüll M, Wimmer $C$, Reichel $O$ et al. Hyperfibrinogenemia as a risk factor for sudden hearing loss. Otol Neurotol 2002; 23(3): 309-311. 